\title{
WANITA DALAM PELAYANAN
}

Gereja adalah milik Kristus dan berada di dunia ini untuk melakukan tugas yang diberikan Kristus kepadanya sesuai dengan Amanat Agung dari Yesus Kristus (Mat.28:1920), maka salah satu tugas penting gereja adalah melayani. Melayani dapat berarti mengosongkan diri dan menempatkan kepentingan sendiri di bawah kepentingan Tuhan dan kepentingan orang lain. Allah memanggil semua orang percaya untuk melayani dunia dan gereja, bukan melayani diri sendiri. Retnowati mengatakan,

"Gereja-gereja dipanggil untuk menguji kembali struktur gereja dan mengusahakan keseimbangan arti memberi peranan penuh dari seluruh anggotanya tanpa terkecuali baik laki-laki maupun perempuan sama-sama mendapat peran yang seimbang dalam gereja, sehingga mereka benar-benar dapat berperan sesuai dengan bakat dan talentanya masing-masing". 1

Yesus Kristus telah mempercayakan tugas yang mulia kepada umat-Nya. Setiap orang percaya diciptakan untuk melayani (Ef. 2:10) dan diperintahkan untuk melayani (Mat. 20:26-28) sehingga kaum awam merupakan kunci keberhasilan suatu pelayanan dan peranan kaum wanita dalam gereja sangatlah penting. Rick Warren mengatakan, "Tidak ada satu pelayanan yang mampu berdiri sendiri. Karena tidak ada pelayanan yang dapat melaksanakan segala sesuatu yang harus dilakukan oleh gereja, kita harus bergantung pada dan bekerjasama satu sama lain."2

Dalam persekutuan yang merupakan dambaan adalah pelayanan dapat berjalan dengan baik dan lancar. Karena apabila pelayanan berjalan dengan lancar, maka apa yang menjadi tujuan dari persekutuan dapat tercapai. Pelayanan dapat maju apabila setiap anggota-anggotanya turut terlibat dalam pelayanan. Untuk itu kaum wanita memegang

\footnotetext{
${ }^{1}$ Retnowati, Perempuan-perempuan dalam Alkitab (Jakarta: BPK Gunung Mulia, 2004),74.

${ }^{2}$ Rick Warren, Pertumbuhan Gereja Masa Kini (Malang: Gandum Mas, 2000), 377.
} 
peranan penting dalam mendukung kelancaran pelayanan dan kaum wanita dapat berperan jika mereka dibina dan diarahkan untuk memahami tanggung jawab mereka.

Oleh karena itu dengan adanya fakta seperti yang diungkapkan di atas maka dalam makalah ini penulis ingin mengupas sedikit mengenai peranan pelayanan kaum wanita dalam gereja demi kemajuan pelayanan.

\section{Pengertian Peningkatan Peranan Kaum Wanita}

Dalam Kamus, kata "Peningkatan" berarti "Proses, perbuatan, cara meningkatkan (usaha, kegiatan)."3 Sehingga dapat dikatakan bahwa peningkatan adalah suatu proses, atau usaha meningkatkan untuk mendapatkan atau mencapai suatu hasil lebih baik dari hasil sebelumnya.

Peranan berasal dari kata dasar "peran" yang berarti, "Sesuatu yang diharapkan dimiliki oleh orang yang memiliki kedudukan dalam masyarakat."4 Sedangkan "peranan" berarti "Bagian yang dimainkan oleh seorang pemain atau tindakan yang dilakukan seseorang dalam suatu peristiwa."5 Sehingga peranan merupakan suatu bagian atau tugas utama yang dimainkan atau dilakukan oleh seseorang. Untuk kata "wanita" dalam Kamus artinya "perempuan dewasa" . Simon Runtung mengatakan, "Orang dewasa adalah orang yang berumur 25-65 tahun yang memiliki kematangan mental dan spiritual."6 Jadi dapat disimpulkan bahwa kaum wanita adalah orang yang telah dewasa baik secara mental maupun spiritual.

\footnotetext{
${ }^{3}$ Kamus Besar Bahasa Indonesia, s.v. "peningkatan".

${ }^{4}$ Peter Salim dan Yenny Salim , Kamus Bahasa Indonesia Kontemporer (Jakarta: Balai Pustaka, 1994), s.v. "Peran".

${ }^{5}$ Ibid, s.v. "peranan".

${ }^{6}$ Simon Runtung, Catatan Kuliah PWJ II, STT Kibaid, Makale, 2006.
} 
Dengan demikian, peningkatan peranan kaum wanita adalah proses atau usaha untuk meningkatkan suatu kegiatan yang merupakan tugas utama yang dilakukan oleh kaum wanita. Peningkatan peranan kaum wanita penting untuk dilakukan dengan jalan kaum wanita perlu dibimbing dan diarahkan menjadi suatu pribadi yang bertanggung jawab kepada Tuhan, dengan berbagai usaha atau kegiatan yang berdaya guna terhadap seluruh kaum wanita untuk dapat mengembangkan dirinya dalam pelayanan kepada Tuhan. Bestiana Simanjuntak mengatakan, "Gereja bertugas melatih dan melibatkan setiap anggotanya dalam pelayanan yang aktif, baik di dalam lingkungan gereja maupun keluar."7 Untuk itu gereja membuka kesempatan bagi kaum wanita untuk menjalankan peranan mereka, melalui program-program yang telah disepakati bersama. Hal yang senada juga diungkapkan oleh P. Tuhumury bahwa,

"Mengajar orang sedemikian rupa sehingga mereka sungguh beriman kepada Kristus dan terus bertumbuh dalam pengenalan akan Dia sampai mencapai kedewasaan menurut ukuran kepenuhannya (Ef. 4:13). Upaya untuk memperkenalkan dan mengajar tiap-tiap orang tentang Kristus dengan segala hikmat dan kemampuan dari Roh Kudus, serta memimpin dia untuk terus bertumbuh menuju kesempurnaan dalam Kristus (Kol. 1:28)."8

Melalui wadah kaum wanita ini diharapkan akan menghasilkan suatu perubahan ke arah positif yang membawa kemajuan dalam suatu jemaat.

\section{Pengertian Kemajuan Pelayanan}

Kata "kemajuan" berasal dari kata dasar "maju" yang artinya bergerak ke depan, tampil ke muka, menjadi lebih baik, laku, pandai, telah mencapai tingkat keberadaan yang tinggi". Sedangkan untuk kata "kemajuan" berarti "perihal yang berhubungan dengan maju". 9 Sedangkan "pelayanan" menurut Ensiklopedi Perjanjian Baru adalah,

\footnotetext{
${ }^{7}$ Bestiana Simanjuntak, Pedoman Perkumpulan Kaum Wanita (Bandung: Kalam Hidup, 1982), 8.

${ }^{8}$ P. Tuhumury, Diktat Pendidikan Kristen (Makassar: STT Jaffray, 2001), 3.

${ }^{9}$ Kamus Besar Bahasa Indonesia, s.v. "maju, kemajuan".
} 
"Pelayanan dari kata Latin, "ministerium" yaitu peranan yang diterima melalui pertunjukan resmi dan yang diwujudkan dengan "wibawa" dengan kata ini disebut pula berbagai jenis kuasa sipil, pelayanan liturgis Yahudi, status Yesus Kristus sebagai Imam, juga wibawa-Nya yang akhirnya beberapa fungsi yang dipercayakan kepada umat beriman. Kemudian kata-kata Yunani yang utama berkaitan dengan pelayanan Kristen ialah dari diakonia "pelayanan", exousia yaitu wibawa, kuasa, oikonomia yaitu tata usaha, kharis/kharisma yaitu pemberian cuma-cuma."10

Dalam Kamus, kata "pelayanan” sama dengan "layan, melayani yang berarti: 1 . membantu menyiapkan (mengurus) apa yang diperlukan seseorang; meladeni; 2. menerima (menyambut) ajakan tantangan, serangan, dsb). Sedangkan "pelayanan berarti perihal atau cara untuk melayani."11 Sehingga pelayanan adalah segala sesuatu yang dilakukan dengan berbagai cara sesuai dengan kuasa atau kemampuan yang ada pada pribadi seseorang yang dalam hal ini berkaitan dengan pelayanan Kristiani.

Dari pernyataan di atas maka dapat disimpulkan bahwa kemajuan pelayanan adalah suatu keadaan yang menunjukkan adanya peningkatan menjadi lebih baik dari sebelumnya dalam hal kegiatan yang dilakukan dengan berbagai cara sesuai dengan kharisma yang dimiliki oleh seseorang. Kemajuan pelayanan yang penulis maksud di sini ialah apabila ada peningkatan hingga mencapai $75 \%$

\footnotetext{
${ }^{10}$ Ensiklopedi Perjanjian Baru, s.v. "pelayanan"

${ }^{11}$ Depdikbud, Kamus Besar Bahasa Indonesia Edisi Kedua (Jakarta: Balai Pustaka, 1995), 571.
} 


\section{DASAR ALKITAB PELAYANAN KAUM WANITA}

Alkitab merupakan dasar untuk melaksanakan berbagai pelayanan dan yang menekankan bahwa setiap orang percaya harus turut terlibat dalam pelayanan. Berikut ini akan diuraikan tentang dasar-dasar Alkitabiah tentang peranan kaum wanita dalam pelayanan:

\section{Perjanjian Lama}

Dalam Perjanjian Lama, nampak mengenai para wanita-wanita yang dipilih dan dipakai oleh Allah untuk menyatakan kuasa dan kehendak-Nya bagi dunia ini. Allah tidak memandang rendah kaum wanita sebagai kaum yang lemah tetapi justru Allah menciptakan manusia untuk bersama-sama dengan kaum laki-laki melaksanakan amanat Tuhan di dunia ini (Kej. 2:8-25).

Sekalipun pada dasarnya wanita sama derajatnya dengan laki-laki, tetapi karena akibat dosa yang dilakukan perasamaan itu telah berubah sebagaimana Tuhan katakan kepada wanita, laki-laki akan berkuasa atasmu (Kej. 3:16). Namun, hal ini bukan berarti kaum wanita sama sekali tidak bernilai, tetapi hanya ada perubahan kedudukan antara lakilaki dan perempuan. Oleh sebab itu mereka harus bersama-sama memenuhi tanggung jawab terhadap Allah sebagai pencipta mereka (Kej. 2:18).

Tetapi dalam Perajanjian Lama, tradisi Yahudi dan Hukum Taurat memandang kedudukan kaum wanita lebih rendah dari laki-laki. Hal ini mulai nampak dalam keluarga Yakub di mana anak-anak Yakub sebenarnya 13 orang termasuk Dina tetapi yang disebutkan dalam Alkitab hanya 12 laki-laki saja (Kej. 35: 22-26). Karena kekangan hukum agama dan budaya dalam konteks Yahudi kaum wanita dipandang lebih rendah dari 
laki-laki. Dalam kalangan mereka wanita tidak terlalu diperhatikan di muka umum sebab tempat umum adalah cocok untuk kaum pria.

Namun pada kenyataannya dalam Perjanjian Lama ada juga kaum wanita yang mempunyai potensi besar sekalipun dalam konteks Yahudi wanita dipandang lebih rendah derajatnya. Wanita yang dipakai oleh Tuhan untuk menolong orang lain secara khusus hamba Tuhan di antaranya adalah seorang perempuan Sunem (II Raj. 4:8-22, 32-37). Ia dipakai oleh Allah untuk menolong nabi Eliza dengan memberikan tumpangan dengan pelayanan yang terbaik. Gien Karssen mengatakan, "Perempuan Sunem ini mempunyai perhatian yang besar terhadap dunia di sekitarnya. Ia memikirkan orang lain terlebih dahulu, bukan dirinya sendiri." ${ }^{\prime 2}$ Kepedulian yang besar terhadap orang lain merupakan salah satu bukti tanggung jawab dalam pelayanan. Perempuan ini tidak harus berkhotbah menyampaikan Firman Tuhan tetapi dengan kemampuannya dan melalui kesaksian hidupnya ia telah melayani Allah.

Dalam Kitab Ester diuraikan secara jelas bagaimana perjuangannya untuk menyelamatkan bangsanya. Keterlibatan Ester dalam situasi dan kondisi yang penuh dengan resiko, Ester menunjukkan keberaniannya yang sangat mengagumkan. Retnowati mengatakan, "Ester dapat menjadi mitra laki-laki dan bekerjasama dengan Mordekhai untuk menyusun dan merencanakan suatu tindakan agar dapat menghadapi segala kemungkinan yang dapat terjadi. Perempuan ini telah memakai hidup, kedudukan dan talentanya untuk kepentingan dan keselamatan orang lain."13 Perempuan diciptakan bukan hanya untuk menjadi ibu rumah tangga tetapi lebih dari pada itu, perempuan diciptakan untuk bergandengan tangan dengan laki-laki, bekerjasama melakukan tugas mulia dari

\footnotetext{
${ }^{12}$ Gien Karssen, Ia Dinamai Perempuan (Bandung: Kalam Hidup, 1974), 112.

${ }^{13}$ Retnowati, Perempuan-Perempuan Dalam Alkitab (Jakarta: BPK Gunung Mulia, 2004), 38.
} 
Allah. J. H. Bavinck mengatakan, "Kebudayaan apapun juga jika mau menerima pendidikan Kristen, pikirannya akan terbuka dan memandang bahwa antara kaum wanita dan kaum pria ada persamaan rohani dan sama derajatnya di hadapan Tuhan, dengan demikian kaum pria tidak berhak/berkuasa secara absolut terhadap kaum wanita.”

Hal yang sama juga dikehendaki Allah dalam hidup setiap anggota kaum wanita untuk memakai keberadaan hidup mereka bagi kemuliaan nama Tuhan meskipun ada hambatan atau tantangan tetapi itu tidak akan menghalangi Tuhan untuk menyatakan rencana-Nya bagi umat-Nya.

\section{Perjanjian Baru}

Dalam Perjanjian Baru juga dikisahkan tentang wanita yang melayani Tuhan Yesus. Mereka melayani Dia, baik dalam perjalanan-perjalanan-Nya (Luk 8: 2; Mark. 15: 40-41), maupun di rumah (Luk. 10: 38-42). Dalam Kisah Para Rasul 1:14 dijelaskan bahwa kaum wanita berkumpul bersama-sama dengan orang-orang lain pada hari Pentakosta dan mereka juga dipenuhi oleh Roh Kudus. Ini berarti bahwa mereka tidak tinggal diam ketika ada persekutuan tetapi mereka juga aktif turut mengambil bagian dalam pelayanan bersama dengan orang-orang percaya lainnya.

Selanjutnya dalam Kis. 16:11-15,40 ada Lidia seorang wanita yang berprofesi sebagai penjual kain ungu dari kota Tiatira. Di tengah-tengah kesibukannya sebagai seorang pedagang, ia masih bisa meluangkan waktunya untuk Tuhan. Ia berkomitmen untuk setia kepada Tuhan dan menyatakan tanggung jawabnya melayani Tuhan dengan bersaksi kepada orang lain sehingga ia dapat membawa mereka kepada Tuhan. Gien Karssen mengatakan, "Bagi Lidia, menjadi orang Kristen merupakan hal yang praktis. Ia tidak menjadi seorang biarawati, ataupun seorang penginjil sepenuh waktu. Ia tetap 
mengerjakan usahanya. Ia memperoleh nama yang baik dengan menyerahkan dirinya, usahanya dan harta miliknya bagi pelayanan yang semaksimal mungkin bagi Kristus."14 Meskipun Lidia tidak memegang jabatan sebagai seorang gembala tetapi Lidia memanfaatkan apa yang ia miliki untuk menyokong pelayanan Tuhan.

Ada pula wanita yang namanya disebut di dalam Roma 6:1-2 bernama Febe yang giat dalam pekerjaan Tuhan dengan melayani di sebuah jemaat yaitu jemaat Kengkrea dan yang suka memberi bantuan kepada orang lain. Ia seorang wanita yang penuh tanggung jawab kepada Tuhan dan kepada sesamanya, ia patut menjadi teladan yang baik bagi wanita-wanita masa kini.

Berpedoman kepada hal di atas, maka gereja bertanggung jawab untuk memberdayakan kaum wanita agar dalam diri mereka timbul kerinduan serta keinginan untuk berpartisipasi dalam pelayanan Tuhan dan agar peran mereka sungguh-sungguh nyata membawa pengaruh yang positif bagi pekerjaan pelayanan Tuhan.

\title{
PERANAN KAUM WANITA DALAM PELAYANAN GEREJA
}

\author{
Peranan Kaum Wanita Dalam Pelayanan
}

\section{$\underline{\text { Sebagai Motivator }}$}

Kata motivator berasal dari kata motivasi. Menurut Kamus, "motivasi” berarti "Keinginan, dorongan yang timbul pada diri seseorang baik secara sadar maupun tidak sadar untuk melakukan suatu perbuatan dengan tujuan tertentu; usaha-usaha yang dapat menyebabkan seseorang atau kelompok orang tertentu tergerak untuk melakukan sesuatu

\footnotetext{
${ }^{14}$ Gien Karssen, op cit., 206.
} 
karena ingin mencapai kepuasan atau tujuan yang dikehendaki dengan perbuatannya itu."15 Jadi motivator merupakan penyebab adanya motivasi pada orang lain untuk melakukan sesuatu, atau menjadi penggerak dan pendorong. Selanjutnya Yakob Tomatala mengatakan, "Motivasi adalah kekuatan yang mendorong untuk bertindak, atau dorongan oleh kekuatan dari dalam atau pun dari luar yang dilakukan dengan mendorong atau menarik."

Kaum wanita merupakan bagian dari persekutuan jemaat yang patut mengambil bagian atau peranan penting bagi pengembangan pelayanan. Untuk itu kaum wanita memegang peranan sebagai motivator bagi sesama anggota jemaat untuk melayani sesuai dengan potensi dan kemampuan yang dimiliki.

Sebagai motivator, Tuhan menginginkan setiap kaum wanita dapat berdaya guna dalam pelayanan. Bukan hanya kaum pria yang dapat menjadi motivator tetapi juga bagi kaum wanita melalui tindakannya menjadi teladan sehingga mampu mempengaruhi orang lain dan tentunya motivasi yang dimiliki bertujuan untuk kemuliaan Allah seperti yang dikemukakan oleh Jeff Hammond, "Kehidupan dan pelayanan yang berdasarkan fondasi lain daripada memuaskan hati Allah adalah sama seperti membangun dengan bahan-bahan yang mudah terbakar,....motivasi sejati adalah menyenangkan hati Allah dan dari dasar itu Allah akan memberikan kita keinginan hati kita." ${ }^{\prime 17}$

\footnotetext{
${ }^{15}$ Salim dan Salim, op cit, s.v"motivasi".

${ }^{16}$ Yakob Tomatala, Kepemimpinan yang Dinamis (Jakarta: YT LeadershipFondation Jakarta, 1997), 214.

${ }^{17}$ Jeff Hammond, Kepemimpinan yang Sukses (Jakarta: Yayasan Media Buana Indonesia/Metanoia Publishing, 2000), 36.
} 
Kaum wanita yang memahami tugasnya sebagai motivator akan mampu menggerakkan orang lain ke arah kemajuan dan perkembangan dalam jemaat. Dengan demikian pelayananpun dapat berjalan dengan baik.

\section{$\underline{\text { Sebagai Teladan }}$}

Sebagai orang percaya yang dipakai oleh Allah maka kaum wanita dituntut untuk menjadi teladan. Menurut Kamus kata "teladan" artinya "dapat ditiru, menjadi panutan". ${ }^{18}$ Rasul Paulus menganjurkan bagi setiap orang percaya untuk menjadi teladan dalam segala hal. Karena Paulus sendiri telah menjadi teladan bagi orang percaya. Dalam II Tesalonika 3:9,...karena kami mau menjadikan diri kami teladan bagi kamu, supaya kamu ikuti. Selanjutnya dalam Titus 2: 7 Firman Tuhan mengatakan,....dan jadikanlah dirimu sendiri suatu teladan dalam berbuat baik. Werren W. Wiersbe mengatakan,'Teladan itu meliputi perbuatan baik, ajaran yang sehat, sikap yang sungguh-sungguh dan percakapan yang sehat ssehingga tidak seorang pun bahkan musuh sekalipun dapat menuduh". ${ }^{19}$

Kaum wanita perlu memiliki kesaksian hidup yang baik. Memiliki kehidupan yang dapat diteladani oleh semua orang merupakan modal yang penting untuk melayani Tuhan karena Tuhan berkenan bagi orang yang melayani dalam kesucian hidup. Mary Go Setiawani mengatakan, "Cara mengajar yang efektif adalah menjadikan diri sendiri teladan hidup untuk menyampaikan kebenaran, dan itu merupakan cara yang paling berpengaruh. Kewibawaan seseorang terletak pada keselarasan antara teori dan praktek." ${ }^{20}$ Oleh karena

\footnotetext{
${ }^{18}$ Salim dan Salim, op cit., s.v. "teladan".

${ }^{19}$ Warren W. Wiersbe, Setia Di Dalam Kristus (Bandung: Yayasan Kalam Hidup 1981),145.

${ }^{20}$ Mary Go Setiawani, Pemabruan Mengajar (Bandung: Kalam Hidup, n.d.), 97.
} 
itu kaum wanita harus mampu menjadi teladan sehingga mereka dapat merangsang anggota lainnya untuk ikut serta dalam mendukung pelayanan.

\section{Bentuk-Bentuk Pelayanan \\ $\underline{\text { Pelayanan Liturgis }}$}

Menjadi seorang liturgis merupakan tanggung jawab bagi anggota jemaat tak terkecuali kaum wanita sebagai salah satu bentuk pelayanan mereka kepada Tuhan dan setiap kaum wanita dapat mengambil bagian sebagai liturgis dalam suatu ibadah.

Kaum wanita yang menyadari dan memahami peranan mereka dalam pelayanan akan bersedia mematuhi jadwal dan tugas yang dipercayakan baginya. Herman Soekahar mengatakan bahwa, "Mereka yang telah bersedia menerima tanggung jawab penuh dalam pelayanan ini diberikan jadwal pelayanan dan materi yang harus mereka pedomani."21 Dengan aktif menjadi liturgis, maka kaum wanita melatih diri mereka untuk terbiasa dalam pelayanan.

\section{$\underline{\text { Pendoa }}$}

Salah satu kebutuhan penting dalam menunjang sebuah pelayanan adalah doa karena doa merupakan kekuatan untuk melakukan pelayanan. Anggota jemaat dapat menjadi pendoa yang berkewajiban untuk mendoakan setiap pelayanan yang dilakukan.

Doa merupakan fondasi yang penting untuk pelayanan. Ron Jenson dan Jim Stevens mengatakan, "....doa akan menjadi lebih daripada sekedar program pilihan atau tambahan bagi beberapa orang yang percaya, dan sebaliknya doa akan menjadi kekuatan

\footnotetext{
${ }^{21}$ Herman Soekahar, Bagaimana Memotivasi Jemaat Melayani (Malang: Gandum Mas, 1987),7.
} 
yang mendorong gereja-gereja kita." ${ }^{22}$ Menjadi pendoa memiliki kepentingan yang tidak dapat dipisahkan dari pelayanan. Kaum wanita harus menyadari bahwa pelayanan doa membawa dampak yang positif bagi pengembangan pelayanan sehingga kaum wanita perlu menjadi pendoa untuk pelayanan.

\section{$\underline{\text { Pelayanan Perkunjungan }}$}

Kata "perkunjungan" berasal dari kata dasar "kunjung" yang artinya "Proses, cara, atau perbuatan mengunjungi atau perlewatan. Selanjutnya "mengunjungi" berarti "Mendatangi dengan tujuan menjumpai, menemui, melewati dan sebagainya."23 Jadi perkunjungan adalah proses mendatangi dengan tujuan menjumpai orang yang hendak ditemui.

Perkunjungan merupakan pelayanan yang ditugaskan Tuhan kepada gereja di mana melalui perkunjungan itu Firman Tuhan dapat disampaikan kepada orang-orang yang dikunjungi. J.L.Ch. Abineno mengatakan,

Pertama-tama harus kita ingat, bahwa kunjungan rumah tangga adalah pelayanan yang ditugaskan Tuhan kepada gereja. Karena itu yang harus dilakukan di situ bukanlah hal-hal yang diinginkan oleh keluarga yang dikunjungi. Yang harus dilakukan dalam kunjungan adalah hal-hal yang ada hubungannya dengan Firman Allah. Atau barangkali lebih tepat: hal-hal yang dilihat dalam terang Firman Allah. Di situ kita dapat berbicara mengenai perkawinan, hubungan suami istri, hubungan antara orang tua dan anak-anak, dan lain-lain. ${ }^{24}$

Tidak dapat dipungkiri bahwa gereja-gereja yang ada pada zaman sekarang bertumbuh melalui pelayanan perkunjungan. Untuk itu kaum wanita diharapkan mampu mendukung pertumbuhan gereja melalui pelayanan mereka di bidang perkunjungan.

\section{Urgensi Peningkatan Peranan Kaum Wanita}

\footnotetext{
${ }^{22}$ Ron Jenson dan Jim Stevens, Dinamika Pertumbuhan Gereja (Malang:Gandum Mas, 2000), 32.

${ }^{23}$ Kamus Besar Bahasa Indonesia, s.v. "kunjung, mengunjungi".

${ }^{24}$ J.L. Ch. Abineno, Penatua Jabatannya dan Pekerjaannya (Jakarta: BPK Gunung Mulia, 1997), 39.
} 
Menurut kamus kata "urgensi" adalah keharusan yang mendesak, hal yang sangat penting atau pentingnya."25 Sehingga peningkatan peranan kaum wanita memiliki kepentingan sebagai berikut:

\section{$\underline{\text { Kaum Wanita Berperan Aktif dalam Pelayanan }}$}

Merupakan hal yang terpenting dari peningkatan peranan kaum wanita adalah supaya setiap kaum wanita memahami dan menyadari tanggung jawabnya dalam pelayanan. Ketika ia menyadari tanggung jawabnya maka mereka diharapkan akan terlibat secara aktif dalam pelayanan. Dalam Kamus, kata "aktif" berarti "Selalu berusaha, bekerja dengan sungguh-sungguh supaya mendapat kemajuan atau prestasi yang gemilang." 26 Dengan adanya peningkatan tersebut, kaum wanita diharapkan aktif terlibat dalam pelayanan. Dalam hal ini yang penulis maksudkan dengan keaktifan kaum wanita adalah ketika anggota persekutuan kaum wanita mengikuti $75 \%$ kegiatan-kegiatan yang telah diprogramkan dalam pesekutuan kaum wanita.

Kaum wanita perlu memiliki kemauan yang keras dari dalam hatinya untuk berperan aktif melayani Tuhan sehingga tugas yang dipercayakan kepadanya dapat dilakukan dan diselesaikan dengan baik. Seseorang tanpa kemauan yang keras tidak akan dapat menyelesaikan suatu pekerjaan dengan baik sekalipun itu pekerjaan yang kecil atau pekerjaan yang ringan. Kaum wanita harus diyakinkan serta diarahkan untuk menggali potensi dan membangun kepercayaan diri mereka sendiri kalau mereka itu berharga di mata Tuhan dan layak dipakai oleh Allah.

Kadang yang menghalangi kaum wanita untuk terlibat aktif dalam pelayanan karena kurang mengenal kelebihan atau potensi yang mereka miliki, yang diberikan Tuhan

\footnotetext{
${ }^{25}$ Salim dan Salim, op cit., s.v. "urgensi".

${ }^{26}$ Ibid, s.v. "aktif".
} 
kepadanya untuk mendukung segala bentuk pelayanan. Untuk itu perlu pemahaman bagi mereka, bahwa mereka adalah ciptaan Tuhan yang diberi kemampuan khusus oleh Tuhan sebagaimana yang diungkapkan oleh Bestiana Simanjuntak, "Setiap wanita perlu ditolong untuk bisa menerima dirinya sebagaimana adanya untuk meyakinkan dirinya bahwa dia sungguh-sungguh berharga di mata Tuhan dan mempunyai bakat, karunia dan kemampuan yang dapat dan yang harus dipergunakan dan dikembangkan."27

\section{$\underline{\text { Pelayanan dapat Berjalan secara Maksimal }}$}

Salah satu harapan dalam setiap gereja adalah supaya semua pelayanan dapat berjalan dengan baik dan dari pelayanan itu menghasilkan buah yang baik pula. Tetapi untuk mencapai pelayanan yang maksimal ada saja hal yang merupakan kendala di dalamnya. Yang penulis maksudkan dengan pelayanan yang maksimal yaitu apabila $75 \%$ pelayanan dapat terlaksana dari keseluruhan pelayanan yang telah diprogramkan.

Namun, salah satu faktor penghambat dalam pelayanan ialah kurangnya tenaga atau sumber daya manusia itu sendiri dalam pelayanan. Seringkali seluruh pelayanan terpaksa ditangani sendiri oleh hamba Tuhan atau gembala sidang karena tidak adanya tenaga yang dapat diandalkan untuk menangani pelayanan sehingga ketika gembala sidang sakit atau berhalangan maka pelayananpun menjadi terbengkalai.

Pelayanan bagi Kristus bukan suatu pilihan tetapi merupakan suatu keharusan bagi setiap orang Kristen. Andar Ismail mengatakan, "Tiap warga gereja adalah pelayan gerejawi....karena pada hakikatnya tiap orang Kristen adalah pelayan Tuhan.”28 Tidak semua orang dipanggil untuk menjadi gembala sidang atau pendeta, tetapi semua orang percaya menerima tanggung jawab untuk memajukan pelayanan serta menjadi saksi

\footnotetext{
${ }^{27}$ Bestiana Simanjuntak, Pedoman Perkumpulan Kaum Wanita (Bandung: Kalam Hidup, 1981), 15.

${ }^{28}$ Andar Ismail, Selamat Melayani Tuhan (Jakarta: BPK Gunung Mulia, 2004),94.
} 
Kristus. Prinsip ini juga terdapat dalam I Petrus 2:9 yang menyebut gereja sebagai "Bangsa yang terpilih, imamat yang rajani bangsa yang kudus, umat kepunyaan Allah sendiri." Sebutan "imamat yang rajani” dapat berarti bahwa semua warga gereja adalah imam yang mengabdikan diri kepada pelayanan karena itu semua warga gereja perlu untuk dibimbing dan diarahkan untuk bisa melakukan suatu pelayanan yang berdaya guna untuk Tuhan.

Pelayanan tidak dapat berjalan dengan baik jika hanya gembala sidang yang berperan di dalamnya. Untuk itu kaum wanita dipanggil untuk turut berperan serta menangani pelayanan. Sebagaimana yang diungkapkan oleh Anne Borrowdale, "Wanita diciptakan dalam citra Allah dengan banyak dan beraneka ragam dan berkreativitas di dunia ini. Mereka dipanggil untuk melayani tubuh Kristus dengan berkat apapun yang mereka miliki."29

Untuk itu melalui peningkatan peranan kaum wanita diharapkan pelayanan dapat berjalan sebagaimana mestinya. Dengan demikian pelayanan kaum wanita dalam gereja itu sangat dibutuhkan. Kalau pelayanan hanya didominasi oleh kaum laki-laki saja atau hanya orang tertentu saja maka dapat dipastikan bahwa pelayanan tidak akan dapat berhasil dengan baik. Retnowati mengatakan, "Tanpa peran dan keterlibatan perempuan di dalam gereja berarti gereja tidak dapat mengekspresikan berita dan pelayanannya secara utuh dan optimal."30 Hal ini berarti kaum wanita dituntut untuk bekerjasama dengan anggota jemaat lainnya, bertanggung jawab memajukan pelayanan gereja serta membantu menunaikan tugasnya.

Faktor Penghambat Peningkatan Peranan Kaum Wanita

\footnotetext{
${ }^{29}$ Anne Borrowdale, Tugas Rangkap Wanita (Jakarta: BPK Gunung Mulia, 1997), 110.

${ }^{30}$ Retnowati, op cit., 84.
} 


\section{Kesibukan Rumah Tangga}

Keluarga adalah lembaga pertama yang didirikan oleh Allah di dunia ini. Untuk itu Allah menginginkan agar setiap orang bertanggung jawab menjaga keutuhan rumah tangganya. Kepala rumah tangga berkewajiban mencari nafkah untuk keluarganya dan tentu saja ibu rumah tangga berkewajiban mengurus rumah tangga dan anak-anak.

Anne Borrowdale mengemukakan tentang sebuah pepatah yang mengatakan, "Pekerjaan seorang wanita tidak pernah selesai, mencerminkan betapa luasnya tanggung jawab wanita."31 Hal ini memang benar adanya karena mengingat kodratnya sebagai seorang perempuan yang diharuskan untuk rajin mengatur rumah tangganya (Titus 2: 3-5) dan pekerjaan ini tidak dapat dipisahkan dari kehidupan seorang wanita. Dengan demikian tidak jarang ada wanita yang menutup diri untuk kegiatan-kegiatan di luar termasuk dalam urusan pelayanan di gereja.

Tetapi Evang Darmaputera mengatakan, "Kalau pekerjaan rumah tangga sudah menjadi kegiatan yang paling penting dan dianggap satu-satunya tugas yang harus dikerjakan sehingga tidak ada lagi waktu untuk yang lain, hal ini amat berbahaya."32 Dikatakan berbahaya karena hal itu berarti bahwa tidak ada kesempatan untuk melakukan kegiatan-kegiatan yang lain termasuk dalam kegiatan melayani, sementara pelayanan merupakan bagian terpenting dari kehidupan setiap orang percaya.

Suatu pelajaran yang penting dari kisah Maria dan Martha (Luk. 10:38-42). Maria selalu meluangkan waktunya untuk mendengarkan Yesus sementara Martha terlalu sibuk dengan kebutuhan jasmani sehingga ia tidak ada kesempatan untuk mendengarkan Yesus.

\footnotetext{
${ }^{31}$ Anne Borrowdale, op cit., 43.

${ }^{32}$ Evang Darmaputera, Wanita dan Berbagai Segi Kehidupannya (Jakarta:: BPK Gunung Mulia, 1997), 31.
} 
Kesibukannya telah menghalanginya untuk menerima dan mengalami sesuatu yang sangat penting dalam hidupnya.

\section{$\underline{\text { Kurangnya Pembinaan }}$}

Tidak dapat dipungkiri bahwa pembinaan sangat dibutuhkan dalam pelayanan karena hal itu merupakan bekal yang dapat mengarahkan setiap orang untuk melakukan suatu pelayanan. Menurut Kamus Besar Bahasa Indonesia, pembinaan berarti: 1. Proses, perbuatan, cara membina; 2. pembaharuan, 3. usaha, tindakan dan kegiatan yang dilakukan secara berdaya guna dan berhasil guna untuk memperoleh hasil yang baik."33 Sehingga “pembinaan" berarti proses membina, membangun, penyempurnaan dan perbaikan, yang dilaksanakan dengan tujuan untuk mendapatkan perubahan ke arah yang lebih baik.

Hal yang menyebabkan seseorang mengabaikan pelayanan karena kurangnya kesadaran akan tanggung jawabnya dalam pelayanan. Kurangnya pembinaan merupakan faktor kendala dalam peningkatan pelayanan kaum wanita. Pembinaan memegang peranan penting untuk memotivasi seseorang melakukan pelayanan. Dengan pembinaan seseorang dapat menemukan percaya dirinya dan menemukan potensi yang mereka miliki. Untuk itulah mereka perlu dibina dan diarahkan agar mereka memahami tanggung jawab mereka sebagai orang percaya. Herman Soekahar mengatakan,

"....bagaimanapun juga hal memotivasi jemaat melayani adalah tuntutan pelayanan yang mendesak pada zaman ini. Itu merupakan tanggung jawab para pemimpin gereja dan para aktifis Kristen kalau ia ingin melihat pertumbuhan iman jemaat yang normal, kalau ingin mengalami keadaan "ringan sama dijinjing berat sama dipikul" dan kalau ingin melihat masa depan pelayanan yang cerah."34

Gembala sidang atau pemimpin jemaat bertanggung jawab membina setiap anggota jemaat karena tugas pembinaan merupakan amanat dari Tuhan Yesus yaitu, ....dan ajarlah

\footnotetext{
${ }^{33}$ Kamus Besar Bahasa Indonesia, s.v., "pembinaan”.

${ }^{34}$ Herman Soekahar, Bagaimana Memotivasi Jemaat Melayani (Malang: Gandum Mas, 1987), 76.
} 
mereka (Mat. 28:20). Lanjut Herman Soekahar mengatakan, ”...para pemimpin rohani perlu didorong mau membimbing, mengarahkan, dan mengkader anggota jemaatnya agar siap hati untuk menerima tongkat estafet pelayanan tersebut."35

\section{$\underline{\text { Lingkungan }}$}

Berbicara mengenai masalah lingkungan berarti berbicara mengenai adat atau kebiasaan-kebiasaan yang berlaku dalam suatu masyarakat tertentu. Menurut kamus kata Lingkungan berarti "Kesatuan ruang dengan semua benda, daya, keadaan dan makhluk hidup termasuk manusia dan perilakunya yang mempengaruhi perikehidupan dan kesejahteraan manusia serta makhluk hidup yang lainnya yang di dalamnya ada nasehat, norma dan cara hidup masyarakat disekelilingnya."36

Pandangan yang mengatakan bahwa tugas kaum wanita adalah mengurus rumah tangganya nampaknya masih berpengaruh besar dalam masyarakat dewasa ini secara khusus bagi masyarakat pedesaan, sehingga seakan-akan membatasi ruang gerak mereka untuk hal-hal atau urusan-urusan yang lain. Sebagai makhluk sosial tentunya manusia membutuhkan orang lain dan perlu untuk bergaul serta mengembangkan dirinya.

Kaum wanita perlu dituntun untuk keluar dari anggapan-anggapan yang demikian karena kaum wanita memiliki potensi dan keterampilan-keterampilan yang tidak dimiliki oleh kaum laki-laki. Kaum wanita perlu dibebaskan dari predikat sebagai kaum yang lemah dalam masyarakat karena dengan demikian dapat membangun kepercayaan diri mereka untuk membuka diri terhadap hal-hal yang lain secara khusus terhadap pelayanan.

\footnotetext{
${ }^{35}$ Herman Soekahar, op cit., 69.

${ }^{36}$ Salim dan Salim, op cit., s.v. "lingkungan".
} 


\section{KESIMPULAN}

Gereja dipanggil untuk melakukan tugas yang dipercayakan Kristus kepadanya, sesuai yang dinyatakan dalam amanat agung-Nya (Mat.28:19-20). Salah satu tugas penting itu adalah melakukan pelayanan. Karena pelayanan ini ditujukan kepada Gereja, hal ini berarti bahwa semua dituntut melayani tanpa terkecuali kaum wanita. Untuk itu kaum wanita juga memegang peranan penting dalam mendukung kelancaran dan kemajuan pelayanan .

Alkitab merupakan dasar untuk melaksanakan berbagai pelayanan dan yang menekankan bahwa setiap orang percaya harus turut terlibat dalam pelayanan. Mengenai pelayanan kaum wanita dalam Perjanjian Lama maupun Perjanjian Baru nampak mengenai

para wanita yang dipilih oleh Allah sendiri dan dipakai untuk menyatakan kuasa dan kehendak-Nya bagi dunia ini. Allah tidak pernah memandang rendah kaum wanita tetapi justru Allah menciptakannya bersama-sama dengan kaum laki-laki melaksanakan amanat Tuhan di dunia ini.

Peranan kaum wanita dalam pelayanan akan sangat besar apabila bisa diberdayakan dan dioptimalkan dengan baik. Mereka dapat berperan aktif sebagai pelayan liturgis, pendoa, pelayanan perkunjungan dan pelayanan lain yang bisa berdampak pada kemajuan pelayanan dan pertumbuhan gereja. Akan tetapi ada faktor-faktor tertentu yang dapat mengakibatkan terhambatnya palayanan kaum wanita apabila tidak mendapat solusi yang tepat seperti kesibukan rumah tangga, kurangnya pembinaan dan pengaruh lingkungan.

\section{DAFTAR PUSTAKA}

Abineno, J.L. Ch. Penatua Jabatannya dan Pekerjaannya. Jakarta: BPK Gunung Mulia, 1997.

Borrowdale,Anne Tugas Rangkap Wanita. Jakarta: BPK Gunung Mulia, 1997. 
Darmaputera,Evang Wanita dan Berbagai Segi Kehidupannya. Jakarta:: BPK Gunung Mulia, 1997.

Depdikbud, Kamus Besar Bahasa Indonesia Edisi Kedua. Jakarta: Balai Pustaka, 1995.

Hammond, Jeff Kepemimpinan yang Sukses. Jakarta: Yayasan Media Buana Indonesia/Metanoia Publishing, 2000 .

Ismail,Andar Selamat Melayani Tuhan. Jakarta: BPK Gunung Mulia, 2004.

Jenson, Ron dan Jim Stevens, Dinamika Pertumbuhan Gereja. Malang:Gandum Mas, 2000.

Kadjakoro, Yolanda. 2019. "Konsep Prajurit Allah Berdasarkan Efesus 6:10-20 Dan Implementasinya Dalam Kehidupan Orang Percaya”. Jurnal Ilmiah Religiosity Entity Humanity (JIREH) 1 (1), 40-56. https://doi.org/10.37364/jireh.v1i1.6.

Marsi Bombongan Rantesalu. "ANALISIS TENTANG PEMAHAMAN IBADAH MENURUT MAZMUR 50 PADA MAHASISWA STAKN KUPANG.” VISIO DEI: JURNAL TEOLOGI KRISTEN 1, no. 2 (18 Desember 2019). https://doi.org/10.35909/visiodei.v1i2.50.

Karssen, Gien Ia Dinamai Perempuan. Bandung: Kalam Hidup, 1974.

Rantesalu, Marsi Bombongan, dan Iswanto Iswanto. "Toleransi Berdasarkan Cerita Rakyat Tallu To Sala' Dadi di Toraja." BIA': Jurnal Teologi dan Pendidikan Kristen Kontekstual; Vol 1, No 1 (2018): JuniDO - 10.34307/b.v1i1.16, 30 Desember 2018. http://www.jurnalbia.com/index.php/bia/article/view/16.

Retnowati, Perempuan-Perempuan Dalam Alkitab. Jakarta: BPK Gunung Mulia, 2004.

Retnowati, Perempuan-perempuan dalam Alkitab.Jakarta: BPK Gunung Mulia, 2004..

Runtung Simon, Catatan Kuliah PWJ II, STT Kibaid, Makale, 2006.

Salim, Peter dan Yenny Salim, Kamus Bahasa Indonesia Kontemporer. Jakarta: Balai Pustaka, 1994), s.v. "Peran".

Setiawani, Mary Go Pemabruan Mengajar. Bandung: Kalam Hidup, n.d.

Simanjuntak, Bestiana Pedoman Perkumpulan Kaum Wanita. Bandung: Kalam Hidup, 1982.

Soekahar Herman, Bagaimana Memotivasi Jemaat Melayani. Malang: Gandum Mas, 1987.

Soekahar, Herman Bagaimana Memotivasi Jemaat Melayani. Malang: Gandum Mas, 1987.

Tomatala, Yakob Kepemimpinan yang Dinamis. Jakarta: YT LeadershipFondation Jakarta, 1997.

Tuhumury, P. Diktat Pendidikan Kristen. Makassar: STT Jaffray, 2001.

Warren Rick, Pertumbuhan Gereja Masa Kini. Malang: Gandum Mas, 2000.

Wiersbe, Warren W. Setia Di Dalam Kristus. Bandung: Yayasan Kalam Hidup 1981. 
